\title{
Advogados “corajosos”: Uma análise da produção de identidade(s) nos conflitos intraprofissionais numa comarca do interior
}

\author{
"Courageous" lawyers: An analysis of the production of \\ identit(y/ies) in intra-professional \\ conflicts in a country side District Court
}

\author{
Pedro Heitor Barros Geraldo \\ Victória Brasiliense de Castro Pires ${ }^{2}$
}

\section{RESUMO:}

Este artigo analisa como as formas de reconhecimento de prerrogativas profissionais são mobilizadas pelos advogados a partir do conflito entre um grupo de advogados e uma juíza em uma pequena cidade no interior de Minas Gerais. A pesquisa de campo foi realizada através da análise dos documentos, observação participante e conversas informais com os advogados da cidade. O conflito produziu sentidos sobre as formas de identificação profissional, mas também pela articulação de estratégias de ação para mobilizar atenção para o conflito na defesa das prerrogativas profissionais. Isto produziu uma divisão entre os dois grupos, um aliado e outro reconhecido entre eles por sua "coragem" ao produzir demandas contra à juíza. Tais estratégias compreendem a utilização de recursos judiciais e administrativos, como denúncias formalizadas ao Tribunal de Justiça do Estado de Minas Gerais e ao Conselho Nacional de Justiça, mas também se articulou por meio de denúncias na mídia e a articulação com a política local. Ao acionarem diversas formas de controle burocráticos da organização judiciária, os sujeitos produziram distintos significados da sua identidade profissional, na e para além da dimensão do reconhecimento burocrático da demanda, englobando aspectos profissionais e políticos. Isto reforçou identidades e hierarquias profissionais entre as profissões do direito.

Palavras-chave: Profissões Jurídicas; prerrogativas;conflito.

\footnotetext{
${ }^{1}$ Professor Adjunto do Departamento de Segurança Pública e Vice-diretor do Instituto de Estudos Comparados em Administração de Conflitos da Universidade Federal Fluminense. Pesquisador do INCT-InEAC (Instituto de Estudos Comparados em Administração Institucional de Conflitos) e Professor Permanente do Programa de Pós-graduação em Sociologia e Direito (PPGSD-UFF). pedrogeraldo@id.uff.br

${ }^{2}$ Mestranda em Ciências Jurídicas e Sociais pelo Programa de Pós-Graduação em Sociologia e Direito da Universidade Federal Fluminense.victoria_bcpires@hotmail.com
} 


\begin{abstract}
:
This article analyzes how forms of recognition of professional prerogatives are mobilized by lawyers from the exemplary conflict between a group of lawyers and a judge in a small city in the country side of Minas Gerais. Field research was conducted through document analysis, participant observation, and informal conversations with city attorneys. The conflict produced meanings about the forms of professional identification, but it also produced the articulation of strategies of action to call attention to the conflict in the defense of professional prerogatives. A division between the two groups was produced, one aligned with the judge and another recognized among them for their "courage" in producing lawsuits against the judge. These strategies include not only the use of judicial and administrative appeals, such as formal complaints to the Court of Justice of the State of Minas Gerais and to the National Justice Council, but also reports local media and the articulation with local politics. By activating various forms of bureaucratic control of the judicial organization, the subjects produced different meanings of their professional identity, in and beyond the bureaucratic dimension of the recognition of their demand, encompassing professional and political aspects. This has reinforced professional identities and hierarchies among the law professions.
\end{abstract}

Keywords: Juridical professions; prerogatives; conflict 
"A advocacia não é profissão de covarde" (Sobral Pinto). Cartaz da OAB

\section{Introdução}

Maria Da Glória Bonelli (1998) conceitua como "mundo do direito" as relações transcorridas em decorrência do trabalho compartilhado nesse campo, ressaltando a competição profissional como característica inerente ao "mundo do direito". De acordo com Eliot Freidson (1998, p. 106) a competição entre profissões pela jurisdição sobre uma determinada área pode ser analisada “(...) como definições conflitantes da natureza do problema ou atividade que cada um está tentando controlar, e reivindicações sobre a maneira pela qual podem ser melhor resolvidos e conduzidos."

Bonelli (1998) explica que a competição profissional no "mundo do direito" pode ser percebida a partir de dois prismas complementares. Um deles diz respeito à estratificação das próprias profissões e refere-se à competição entre os pares profissionais, é o que a autora denomina como competição intraprofissional. O outro é definido como competição interprofissional e baseia-se nas tensões entre profissões diferentes que possuem atuações de trabalho em áreas fronteiriças e que buscam submeter sua forma particular de lidar com as questões comuns umas as outras (BONELLI, 1998; 2010).

Este trabalho analisa as disputas intraprofissionais na advocacia a partir da descrição das práticas de mobilização profissional em torno da "defesa de prerrogativas"numa comarca do interior de Minas Gerais.Observamos como os advogados produziram estratégias num conflito profissional entre um grupo de advogados "corajosos", que se posicionou intensamente como contrários a uma magistrada, e essa juíza. A pesquisa de campo permitiu observar, assim, como as interações entre os pares profissionais e entre profissionais de áreas vizinhas são constitutivas das identidades profissionais.

A disputa interprofissional acirrada entre os advogados e a juíza envolveu denúncias administrativas e penais de ambos os lados. Apesar disso, este trabalho não teve como objetivo, nem se constituiu enquanto problema de pesquisa, produzir um juízo de valor sobre as posições dos atores ou a justeza de suas razões. Estas acusações recíprocas, ao serem mobilizadas por meio de instrumentos jurídicos, constituem usos profissionais que são tidos aqui como objetos de reflexão. Por isto, não se pretende denunciar o conflito, mas descrever como estas acusações são realizadas pelos atores envolvidos. Afinal, são práticas de produção 
de significados sobre a profissionalidade dos advogados que, mobilizando-se diante do conflito com a juíza, se identificam como "corajosos".

O trabalho de campo, que consistiu em observação participante, foi realizado em uma comarca de pequeno porte que possui duas varas, ocupadas por uma juíza e por um juiz. Há, aproximadamente, 180 advogados inscritos na Ordem dos Advogados do Brasil (OAB) na cidade. O mercado desses profissionais se caracteriza por escritórios solo e de pequeno porte, em que trabalham entre dois e três advogados, não raro, com vínculos de parentesco como irmãos ou cônjuges. Optamos por não identificar o local da pesquisa para preservar a identidade dos atores e interlocutores.

A pesquisa também envolveu a consulta a reportagens veiculadas pela mídia regional e documentos produzidos pelos atores envolvidos no conflito, como por exemplo, reclamações formalizadas ao Tribunal de Justiça do Estado de Minas Gerais (TJMG) e ao Conselho Nacional de Justiça (CNJ), boletins de ocorrência, ações penais, entre outros.

A análise sobre a questão das prerrogativas apenas surgiu nesta pesquisa com o decorrer do trabalho de campo. E apesar de ter sido mobilizada diversas vezes nas falas dos interlocutores, só foi compreendida quando dita em uma situação específica. Em uma reunião entre os representantes da OAB local e o corregedor-geral de Justiça do TJMG.

Éramos um grupo de oito pessoas que aguardavam, na antessala, o atendimento do corregedor. Nesse tempo de espera, o procurador de prerrogativas da OAB ao conversar com um dos advogados do grupo lhe explicou sobre esta pesquisa. Ele disse, justificando a presença de um pesquisador naquele lugar, que realizávamos "uma pesquisa sobre prerrogativas".

Nesse momento ele disse como eles, advogados, viam esta pesquisa, mas mais do que isso, o que o conflito com a juíza significava para este grupo. É uma pesquisa sobre prerrogativas, porque é disso que se trata o conflito, "a briga com a juíza" é uma questão de prerrogativas. É a utilização dessa fala como pauta principal da "briga com a juíza" que traz para o centro deste trabalho as discussões sobre identidades profissionais na advocacia. A partir de um entendimento que possibilita repensar as profissões como unidade, no sentido de um grupo com capacidade geradora de sentimentos partilhados, para compreender que as práticas profissionais e as normas que as orientam não são significadas e simbolizadas de forma idêntica pelo mesmo grupo profissional (BONELLI, 2005). O objetivo deste trabalho é discutir como associação, por meio da competição inter e intraprofissionais (Bonelli, 1998) e 
da sociabilidade profissional, atua no sentido de construir e ressignificar diferentes representações sobre o exercício da profissão de advogado numa pequena cidade do interior.

As prerrogativas profissionais dos advogados são definidas pela Lei ${ }^{\circ}$. 8.906, também conhecida como, Estatuto da OAB. Segundo esse dispositivo normativo, as prerrogativas envolvem: não haver hierarquia entre magistrados, membros do Ministério Público e advogados, devendo tratarem-se com consideração e respeito; tratamento compatível com a dignidade da advocacia; exercer a profissão com liberdade em todo o território nacional; inviolabilidade do escritório ou local de trabalho do advogado, bem como de seus instrumentos de trabalho e correspondências; comunicar-se com seus clientes mesmo sem procuração quando estes estiverem presos ainda que incomunicáveis; ter a presença de um representante da $\mathrm{OAB}$ quando preso em flagrante por motivo relacionado ao exercício profissional; não ser recolhido preso antes de sentença transitada em julgado senão em sala que lhe assegure condições dignas; ingressar livremente nas salas de sessões dos tribunais, nas salas e dependências de audiências, secretarias, cartórios, ofícios de justiça, serviços notariais e de registro, delegacias, prisões, em qualquer local que funcione repartição judicial ou outro serviço público onde o advogado deva praticar ato ou colher prova e em qualquer assembleia ou reunião de que participe ou possa participar seu cliente; permanecer sentado ou em pé, como também, o direito de retirar-se dos lugares anteriormente citados; dirigir-se diretamente aos magistrados nas salas e gabinetes do trabalho, independente de horário marcado ou qualquer outra condição; usar da palavra pela ordem em qualquer juízo ou tribunal; reclamar verbalmente ou por escrito perante qualquer juízo, tribunal ou autoridade contra a inobservância de preceito de lei; falar sentado ou em pé em qualquer tribunal ou órgão de deliberação coletiva da Administração Pública ou do Poder Legislativo; examinar e consultar autos de qualquer natureza mesmo sem procuração; ter vistas dos processos; ser publicamente desagravado quando ofendido no exercício da profissão.

Conforme consulta ao site da OAB/MG o estado possui 77 delegados de prerrogativas, que são advogados que prestam serviço voluntário à Ordem para atuarem na defesa das prerrogativas dos colegas.

\section{A "briga com a juíza"}

Os advogados se referiam com frequência à "briga com a juíza”. Para compreender a "briga", privilegiaremos a dimensão intraprofissional entre os advogados. Bonelli(2010) 
explica como essa dimensão profissional dos conflitos pode ser compreendida articulando-se os contextos, os interesses dos atores envolvidos e as finalidades e possibilidades de intervenção das diferentes profissões do "mundo do direito".

No entanto, o conflito intraprofissional foi desencadeado a partir de um conflito interprofissional compreendido pelos advogados, como eles explicam, em torno de controvérsias sobre a "defesa de prerrogativas" perante a atuação profissional de uma magistrada. Assim, a análise se restringiuàs práticas dos advogados em conflito e como esses atoresproduziram e (re)significaram suas identidades profissionais.

Os primeiros contatos com aqueles que se tornariam os interlocutores deste trabalho foram realizados a partir de reuniões na sede da OAB local. Este é um espaço utilizado por um grupo de advogados para discutir suas estratégias de mobilização nas questões relacionadas ao conflito com a juíza.

Todavia, por esses encontros entre os advogados serem esparsos, foi acompanhado também uma interlocutora-chave em seu escritório, cotidianamente, por dois meses, de segunda-feira à sexta-feira, de 13:00 às 18:00 horas. Mesmo quando cessaram as idas a esse escritório regularmente, ainda prosseguimos observando as disputas e conflitos envolvendo os atores pesquisados por meio de encontros informais e continuamos acompanhando as estratégias de ações mobilizadas por eles na busca por aliados durante o conflito. Dessa forma, foi possível compreender, do ponto de vista desses interlocutores, o que está acontecendo na comarca. Suas falas estão transcritas no decorrer do texto entre aspas e em itálico.

Para compreender a "briga com a juíza", além das observações e conversas informais, tivemos acesso à denúncia inicial proposta pelos advogados. Apesar do procedimento de sindicância tramitar em segredo no TJMG, os interlocutores disponibilizaram esta denúncia para consulta. Assim, em virtude da publicização desta Reclamação, por parte de seus próprios autores, tivemos acesso a esse documento.

A "briga com a juiza" começou logo nos primeiros meses em que a magistrada foi transferida e assumiu suas funções numa das varas na comarca. Os advogados passaram a procurar a OAB local para registrar reclamações e acusações sobre a atuação profissional da juíza.Os primeiros relatos diziam respeito à questão da juíza não recebê-los em seu gabinete.

De um ponto de vista normativo, o Estatuto da OAB prescreve que todos os advogados possuem livre acesso aos gabinetes dos juízes.Esta é uma prática profissional comum, como observado com frequência no cotidiano desses profissionais. Essas reuniões 
entre advogados e juízes ocorrem, principalmente, motivadas por pedidos dos advogados de celeridade para "dar andamento a determinado processo" por meio de "despachos", isto é, as ordens escritas dos juízes, e a produção de sentenças para encerrar os processos numa "tutela jurisdicional”, como eles explicam.O que se sobressaía nas conversas, num primeiro momento, era a insatisfação coletiva por não serem recebidos e pelo tratamento dispensado na recusa.

Havia, também, comentários de muitos advogados sobre a demora da juíza em emitir tais "despachos" e sentenças. Assim, as queixas sobre a demora na expedição dos "despachos" foi interpretada pelos profissionais, como uma "ausência de prestação jurisdicional".'Isso produzia ainda mais a procura dos advogados pela juíza em seu gabinete. Consequentemente,as recusas em recebê-los, se reproduziam numa prática interpretada negativamente por eles. Pois, aumentava a insatisfação em relação aos clientes dos advogados a quem os profissionais são frequentemente chamados a se posicionar. A ausência de sentenças nos processos dificultava-lhes igualmente o recebimento de honorários, já que esta é uma questão profissional na relação entre advogados e clientes.

Os advogados se queixavam que eram recebidos pela assessora da juíza que negava de pronto o atendimento no gabinete.O acúmulo de trabalho era frequentemente utilizado como razão para não os receber. Para aqueles que às vezes insistiam no atendimento, a insatisfação era justificada pelos advogados por uma confrontação pela juíza,que dizia que eles deveriam escolher entre "ser recebidos ou[deixar] ela trabalhar". Essas queixas se tornaram comuns e foram repetidas muitas vezes pelos diversos interlocutores.

$\mathrm{O}$ fato de que qualquer contato fosse feito sempre por meio da assessora os incomodava. O tratamento jocoso também explicitava esta oposição interprofissional. Era comum em suas explicações rirem ao chamar a assessora de "segurança da juíza" ou de "cão de guarda”. O significado negativo situa essa prática como contrária às práticas de acesso à juíza. Afinal, todos reconheciam que para chegar à juíza era primeiro preciso "passar pela assessora”, como lamentavam os advogados em suas conversas. Assim, a juíza passou a ser vista como figura inacessível aos advogados. Essa prática foi formulada numa Reclamação contra a juíza pela $\mathrm{OAB}$ à corregedoria do TJMG, em que os advogados expuseram que:

O tempo diário da magistrada é dedicado, em grande parte, para reuniões sociais, ou quando não, permanece "trancada", “incomunicável", em sua sala, sem produtividade aparente, em detrimento ao andamento célere do Poder Judiciário de Minas Gerais. (...) A postura da magistrada é a mesma desde seu ingresso na 
magistratura, vez que fatos idênticos ocorreram nas Comarcas anteriores onde atuou (...).

Diante de uma série de reclamações formuladas pelos advogados à assessora, a juíza instituiu um "caderno" para servir de protocolo de atendimento, sujeitando-os à práticas de controle inusuais, do ponto de vista dos advogados. O caderno também foi objeto de "revolta e indignação", como era descrito.Diversos interlocutores descreviam o "caderninho" de uma forma pejorativa explicando que “caderninho não era atendimento”.Na Reclamação, consta que:

\begin{abstract}
A magistrada, que nunca atendeu aos advogados pessoalmente, passou a exigir "formulário próprio", de sua autoria, a fim de evitar o contato pessoal entre ela e Advogados, iniciando o calvário quanto ao atendimento.

As dificuldades criadas pela magistrada, impedindo seu contato direto com os advogados, passaram a preencher a pauta de reuniões da (...) Subseção da OAB/MG, em (...). Com o sistema de formulários, a magistrada se achou desincumbida do dever de atendimento direto ao advogado que é inerente à prestação jurisdicional.

Diante da ineficácia da sistemática de formulário criado pela magistrada, os advogados passaram a se recusar a preenchê-los (doc. 62).
\end{abstract}

O agravamento desse conflito interprofissional produziu novos contornos intraprofissionais. Como no exemplo de uma interlocutora, que relatou aos risos sobre o caso de uma estagiária que havia sido contratada como "assessora da assessora", ao que um advogado completou que agora eles eram atendidos estritamente por essa funcionária, pois nem a assessora estaria mais disponível.

Outro ponto de conflito entre advogados e juíza surgiu em 2015 quando houve a criação do Centro Judiciário de Solução de Conflitos e Cidadania (CEJUS). Este centro de conciliação e mediação foi trazido pela juízae funciona no Fórum da comarca. Sua inauguração foi um evento no Fórum.

A criação do CEJUS foi apresentada como uma "parceria" entre o TJMG e a faculdade privada local que oferta um curso de direito. No evento, estavam presentes e discursaram, a juíza como coordenadora e responsável pelo projeto, o juiz como Presidente do Foro, um desembargador representando o TJMG e o Diretor-Geral da faculdade, um homem com ligações políticas na cidade. Na plateia havia muitos advogados presentes.

De acordo com o que foi dito no dia e com reportagens ${ }^{3}$ que noticiaram o evento, a parceria entre a faculdade privada e o TJMG envolve a seleção de estagiários graduandos em

\footnotetext{
${ }^{3}$ Ver: Reportagens sobre a inauguração do CEJUS: Disponível em: <http://www.iof.mg.gov.br/index.php?/justica/justica/TJ-instala-Cejus-em-Monte-Carmelo.html>; $<$ http://anamages.org.br/noticias/tjmg-instala-centro-judiciario-de-solucao-de-conflitos-em-monte-carmelo>; 
direito para realizarem as audiências de conciliação e mediação. Essa parceria entre o TJMG e a faculdade privada é importante para compreender alguns desdobramentos do conflito interprofissional.

Essa faculdade posicionou-se como um dos aliados da juíza, do ponto de vista dos advogados. Ao empregar advogados que lecionam em seus cursos, os interlocutores afirmavam que "quem trabalha na[faculdade]não pode se manifestar contrário a juíza para não ser demitido".

Em reportagem veiculada no site da Casa Civil do Estado de Minas Gerais há a seguinte declaração fornecida pela juíza

\begin{abstract}
A coordenação da unidade estará sob responsabilidade da juíza (...), que se declarou grande incentivadora da conciliação e da mediação. "Atuo como conciliadora há quase 16 anos, ao longo dos quais pude testemunhar que a oportunidade de comunicação eficiente para a construção de um acordo é a solução que melhor atende aos anseios das pessoas envolvidas em um conflito, além de trazer excelentes resultados aos profissionais da área jurídica", ressalta.

$\mathrm{Na}$ avaliação da magistrada, a implantação do Cejus é "um marco na história da Justiça em (...)", sendo "passo importantíssimo para a conquista de dias melhores para a comarca e também para nos colocarmos em sintonia com o novo Código de Processo Civil". De acordo com a juíza, tramitam hoje na comarca 22 mil feitos, "número em descompasso com os nossos ideais. No fundo, nosso objetivo é um só: queremos resolver os conflitos dos jurisdicionados, de maneira célere e eficiente, cada qual exercendo seu papel nessa nobre missão de pacificação social". (TJ instala CEJUS em (...). Disponível em:

<http://www.iof.mg.gov.br/index.php?/justica/justica/TJ>. Acesso em: 06 de out. de 2017).
\end{abstract}

Alguns meses após essa inauguração, uma reportagem no site do TJMG exaltou que a comarca comemorava os resultados obtidos com a instalação do CEJUS e apresentou índices de quantos "acordos" foram realizados, a manchete dizia: "(Referência ao nome da cidade) comemora resultado positivo de CEJUS em 2015." (Disponível em: $<$ http://www9.tjmg.jus.br/portal/acoes-e-programas/cine-clube/noticias/detalhe1898.htm\#.WdfPR1tSzIU>. Acesso em: 06 de out. de 2017).

Todavia, essa leitura sobre o sucesso da implantação do CEJUS não foi compartilhada por grande parte dos advogados. Havia queixas constantes, tanto formalizadas para a OAB quanto, informais, sobre a falta de treinamento dos estagiários que realizavam as audiências de conciliação e mediação. Eles e os clientes eram coagidos, como relatavam os advogados, pelos estagiários nas audiências, a aceitarem as propostas de acordo formuladas pelas

$<$ http://www.montefm.com.br/noticias/fucamp-firma-convenio-com-tribunal-e-justica-do-estado-de-minasgerais-tjmg/>. Acesso em 06 de out. de 2017. 
empresas rés nos processos. A assessora da juíza era responsável por coordenar diretamente os trabalhos, a magistrada não conduzia de forma presencial essas audiências.

Ao recusar o acordo e o debate com os estagiários se intensificar, a assessora intervinha e, conforme foi relatado, "ameaçava" o advogado dizendo que "se o acordo não fosse aceito, a magistrada julgaria em valor menor do que a proposta de acordo”. Essa prática do "acordo forçado" também é observada em outros contextos entre os profissionais do "mundo do direito" (TORRES DE MELLO RANGEL, 2013, p.73).De acordo com os advogados, o cliente aceitava a proposta "diante da coação", mesmo "não estando satisfeito”. Uma prática igualmente reconhecida pelos profissionais do direito, conforme observou Angela Moreira-Leite (2003, p.99) em sua pesquisa de campo nos Juizados Especiais Cíveis.

Um dos advogados relatou que, ao não aceitar a proposta de acordo de três mil reais, mesmo diante dos constrangimentos impostos na audiência, teve a causa julgada em dois mil reais pela juíza, conforme "ameaça" anterior. A diminuição do valor do pedido, embora seja comum, foi interpretada negativamente pelo advogado que atribuiu a decisão ao conflito interprofissional.

Além disso, a reclamação formalizada pela $\mathrm{OAB}$ explicita que, quando o advogado resistia em aceitar o acordo, a impressão da ata da audiência era atrasada de forma a inviabilizar que o profissional realizasse qualquer outro trabalho no dia. Em "resposta" a essas críticas, como percebiam os advogados, houve a publicação de uma notícia numa revista local, elogiando o trabalho da juíza e dos estagiários no CEJUS. Além disso, houve a publicação de textos no Facebook de estagiárias defendendo o trabalho realizado pelo centro de conciliação. Algumas estagiárias do CEJUS chegaram a citar de forma pejorativa os advogados em seus comentários. Esses comentários estão documentados na Reclamação:

\footnotetext{
O que esses advogados afirmam é que os conciliadores são incapacitados de fazer audiências, que o Cejus não funciona, além de outras reclamações infundadas. Gostaria apenas de esclarecer alguns pontos porque não concordo com tamanha ignorância. Para começar o papel do Cejus é a pacificação, é o local em que as partes buscam para resolver suas demandas por meio da composição, sem necessidade de ajuizar ação. (Reclamação OAB).
}

Conflitos entre advogados e conciliadores são comuns no decorrer das audiências, como observaram Moreira-Leite (2003) e Victor Torres de Melo Rangel (2013). Apesar disso, os interlocutores afirmavam que "a briga" não era com os estagiários, mas sim com a juíza e viam essas manifestações em redes sociais apenas como um ato pensado e ordenado Revista Juris Poiesis - Rio de Janeiro. Vol.21-n²5, 2018, pg.166- 191. ISSN 2448-0517 
pela magistrada. Da mesma forma, negavam que o problema seria o CEJUS em si, para eles, o problema estava "na forma como ele funcionava" na cidade.

A atuação da juíza não apenas no CEJUS, mas também envolvendo outras audiências passou a ser duramente criticada pelos advogados. A juíza “mandar testemunhas calarem a boca" e destratar advogados e partes fazia parte do cotidiano das audiências, segundo os interlocutores.

Os conflitos e as tensões apenas se agravavam. Um advogado disse que "graças a Deus ele ainda não tinha realizado nenhuma audiência com a juíza”. Isso porque, os rumores se espalharam, pois os advogados conversavam entre si e compartilhavam suas experiências. Um dos interlocutores relatou que o "estresse causado pelas decisões sem nexo da juíza" havia provocado a elevação de suas taxas de triglicerídeos e pressão a níveis altíssimos. Ele explicou "decisões sem nexo" como o fato de "ela[juíza] não guardar uma consistência lógica entre os pedidos das peças processuais e as sentenças".

Os representantes da OAB relataram que, mais de uma vez, advogados chegaram aos prantos durante as denúncias e reclamações sobre o comportamento profissional da juíza. $\mathrm{O}$ presidente da OAB local contou que, desde o início dos conflitos, ele "não tem mais sossego", que ele "vive isso todos os dias" e "não consegue trabalhar, pois toda hora tem alguém batendo na porta com algo novo".

$\mathrm{O}$ caso de uma advogada foi bastante citado pelos interlocutores durante a pesquisa e seu relato consta na Reclamação apresentada pela OAB ao TJMG. Ela é uma advogada jovem e a maioria dos processos em que atua são da área de direito penal. Em uma audiência em que defendia um réu preso, a juíza disse, durante a audiência e na presença da promotora de justiça e do cliente, que “a moça era uma péssima advogada”,pois ela não estaria realizando a defesa da forma correta. A juíza disse à advogada que se lembraria dela em todos os processos e anotou seu nome em um caderno.

A advogada solicitou a presença do representante da OAB. De acordo com ela, a juíza teria dito que trataria os advogados conforme mereciam e "mandou” que ela se acalmasse ou seria presa por desacato. Olhando para o cliente, a juíza falou que a advogada o estava prejudicando ao solicitar a $\mathrm{OAB}$, pois impedia que o processo seguisse seu curso normal. Chorando, após o término da audiência, a advogada procurou a OAB para realizar a reclamação. Com o tempo, a tensão entre elas aumentou. Na reclamação formalizada pela $\mathrm{OAB}$, segue um trecho de uma das representações formulada por essa advogada 
No momento a Juíza me convidou para entrar e mais uma vez, mandou sobre mim uma avalanche de críticas, e mais ameaças de não fazer nenhum despacho, enquanto nós (advogados) insistíssemos em atendimentos, pois segundo ela enquanto está atendendo um, poderia estar despachando no processo de outro.

Como se não bastasse me submeteu mais uma vez a um "caderninho", mandou que eu assinasse, como se minha assinatura valesse por um atendimento, o que não é verdade. Aqueles minutos ali não foram de esclarecimentos, conversa sadia, dúvidas, ou qualquer solução que busca um advogado, foi de pura e simples humilhação, em frente a sua assessora e demais trabalhadoras daquela vara.

Relato com uma imensa lástima a este Representante que, nunca me senti tão humilhada quanto naquele momento. (...)

Deixo minha lamentação por tais atitudes, meu desgosto em atuar na $1^{\text {a }}$ vara da Comarca de (...)e meu sincero arrependimento de ter estudado uma vida, para lidar com uma profissional como esta. De saber que ganho a vida tendo que me calar e aguentar humilhações de quem "acha" que é melhor que eu hierarquicamente, mas que infelizmente para ela, não temos nenhuma hierarquia, a não ser a hierarquia da educação, do amor, em especial, do respeito ao próximo. (Reclamaçãoda OAB ao CNJ e Corregedoria do TJMG).(Grifos do texto original).

Há muitos relatos como esse de advogados que se sentiram humilhados pelos comentários da juíza em audiência ou em seu gabinete na presença frequente do Ministério Público e de servidores da vara. Um advogado de mais de 70 anos chorou em diante do presidente do TJMG, quando contou que nunca teria se sentido "tão humilhado" como se sentiu pelo tratamento dispensado pela juíza, em tantos anos de exercício profissional. As queixas se espalharam, os interlocutores diziam que não havia "como trabalhar", "que a juíza é louca”, "uma psicopata”, que "ela não sabe o direito" e "se sente acima da lei", "que ela não despacha e que eles estavam endividados".

Diante de um volume significativo de acusações semelhantes, os representantes locais da $\mathrm{OAB}$ entraram em contato com a Seccional de Belo Horizonte e solicitaram o auxílio e a intervenção da $\mathrm{OAB} / \mathrm{MG}$. Dessa forma, foi enviado à cidade o procurador de prerrogativas da instituição que se reuniu com os advogados e se propôs a mediar o conflito. Em companhia dos representantes da $\mathrm{OAB}$ da cidade eles foram conversar com a juíza, expor as queixas dos advogados e ouvi-la. Ao chegar ao Fórum,uma interlocutora relatou que a assessora lhes impediu a entrada no gabinete da juíza, mas que o procurador de prerrogativas pediu licença à funcionária e forçou a entrada na sala. 
Ele disse à juíza que havia uma série de reclamações feitas pelos advogados, afirmando que "ela não os atendia" e que eles lhe haviam relatado, também, uma orientação para que todos os acordos no CEJUS fossem realizados com a limitação de indenização em dois mil reais. De acordo com o procurador, a juíza não se mostrou disposta a conversar e passou a "rebater tudo" que ele falava. "O que ela aceitava, ela vinha com algo sem sentido", relatou o procurador, e, como exemplo, citou a queixa sobre a limitação em dois mil reais da indenização no CEJUS.

De acordo com seu relato, quando ele falou sobre isso, a juíza não negou o fato, apenas disse que em relação a isso não haveria o menor problema, bastaria que os advogados recorressem das decisões. Por fim, ela disse, segundo os interlocutores, que se $51 \%$ dos advogados da comarca estivessem insatisfeitos com seu trabalho, ela pediria remoção e iria embora da cidade. O presidente da OAB local, respondeu que havia uma lista com assinatura de mais de cinquenta por cento de advogados que reiterava as queixas. No mesmo momento, a juíza pediu para ver a lista e o presidente disse que ele estava ali representando esses advogados e ela não teria acesso a essa lista.

Diante do que foi dito nessa reunião, os representantes da OAB local realizaram uma reclamação à corregedoria do TJMG e ao CNJ. O texto formulou denúncias sobre uma série de irregularidades e pediu a instauração de sindicância com a, consequente, abertura de processo administrativo disciplinar.

Após o protocolo desta reclamação, os advogados se queixavam que as perseguições da juíza aumentaram e que o Tribunal ainda não havia feito nada. Uma série de outras acusações e reclamações foram oficializadas, por meio do site da ouvidoria do TJMG pelos advogados. Os interlocutores explicaram que a juíza ameaçava chamar a polícia militar para redigir boletins de ocorrência contra advogados na tentativa de intimidá-los, pois, conforme eles, não havia qualquer razão para tal atitude. A juíza registrou queixa, por boletim de ocorrência, contra três advogados.

Como a relação entre advogados e juíza apenas se tornava mais tensa, o presidente da $\mathrm{OAB} / \mathrm{MG}$ foi à cidade acompanhado de conselheiros estaduais de comarcas vizinhas, quando se reuniu com os advogados na OAB local e ouviu as acusações. Durante o evento foram afixados cartazes agradecendo à presença do presidente e outros com os muitos dizeres de protesto: "CNJ e TJMG vamos fiscalizar???”; “1 Vara: sem despacho, sem sentença, sem respeito"; "Caderno não é atendimento". A partir desse dia, em todas as manifestações públicas contrárias à juíza, os advogados vestiam-se de preto em sinal de “luto” ao judiciário. 
Usavam, também, desde essa data um adesivo colocado ao peito.Neste adesivo estava escrito: “Advogado valorizado, cidadão respeitado. Luto: Júza $1^{\text {a }}$ Vara. Nome da Comarca.”

Os interlocutores sempre fazem referência a esse evento com os conselheiros e o presidente da $\mathrm{OAB} / \mathrm{MG}$, pois nesse mesmo dia a juíza teria marcado um evento em seu apoio na porta do Fórum. Diante da ausência de plateia, os apoiadores da juíza (a assessora, a estagiária "assessora da assessora" e um conselheiro tutelar) foram para a porta da OAB e fotografaram os advogados ali presentes. Foi necessário que um dos conselheiros estaduais pedisse para que a assessora se retirasse do local, uma vez que se tratava de uma "reunião particular dos advogados", como explicou.

Um dos interlocutores se sentiu muito ofendido com o fato e contou que, até então, não tinha tido nenhum problema com a juíza, mas tinha ido a essa reunião em "solidariedade aos colegas". No entanto, a presença "intimidatória" da assessora os fotografando se tornou o suficiente para que ele se aliasse ao grupo mais combativo no conflito com a juíza. Nas conversas, ele sempre contava consternado sobre esse episódio.

Os advogados diziam que a relação com a juíza era péssima e que não havia mais a possibilidade de um acordo, que esse momento havia passado e que, agora, "o juiz natural” e o "princípio da imparcialidade" estavam comprometidos, como consequência a juíza não poderia julgar as causas desses advogados. Eles relatavam, quando se reuniam na sede da OAB local que a situação havia se tornado uma "guerra" e que não havia mais espaço "para discutir a relação com a juiza”. O rompimento deveria ser "total”, como defendiam. Um deles falou numa reunião da $\mathrm{OAB}$ que, quando fizeram as denúncias, eles se colocaram "numa situação de inimizade capital com a juiza".

Para o presidente da OAB local, a juíza "não só persegue os advogados, como qualquer pessoa que não seja da amizade dela”. Ele explicou também que a juíza visitou entidades de classe para, "segundo ela", distribuir "justiça e amor", mas tais "visitas" seriam para buscar apoio e aliados na sociedade civil e "difamar" os advogados.

\section{O conflito intraprofissional}

O conflito interprofissional entre advogados e a magistrada não provocou uma mobilização unânime entre os advogados. De início, até a manifestação que envolveu as faixas, o grupo contrário à juíza reunia por volta de 90 advogados, havia também, em menor número, aqueles que não se manifestaram. Esses 90 faziam questão de se afirmar como a 
maioria dos "advogados militantes" da comarca, uma vez que à época haviam 116 profissionais inscritos na Ordem.

Para esses advogados, a "militância” é uma característica positiva da profissão.O "advogado militante" é aquele que "atende o cliente", "faz o serviço de balcão", "faz as peças e audiências", dentro da hierarquia profissional eles são vistos como possuindo um prestígio profissional. Contrariamente, àqueles advogados que só fazem audiências, os "audiencistas"; ou que só cumprem diligências, ou do que aqueles que possuem o registro na Ordem, mas apenas estudam para concurso, os “concurseiros”.Para o grupo de advogados, o profissional "militante" é visto como sendo a característica identificadora dos profissionais "corajosos". Em alguns momentos durante a pesquisa, os interlocutores deslegitimaram a oposição de alguns advogados dizendo que "eles não advogam”, "possuem um número reduzido de ações distribuídas" ou "só fazem diligência".

As consequências do conflito foram administradas como uma oposição entre o próprio grupo de advogados. Acrescente tensão entre o grupo de 90 advogados, em princípio todos contrários à juíza,fez com que ele se dividisse em dois. Um deles era explicitamente contrário à magistrada enquanto o outro foi tacitamente interpretado como favorável a ela. Havia alguns advogados que se posicionaram, desde o início, ao lado da juíza perante os colegas e outros que permaneceram contrários a ela somente enquanto o anonimato foi possível. Quando " $a$ briga" envolveu a necessidade de se manifestar nos processos individualmente, por meio da alegação dos incidentes de suspeição, esses advogados "trocaram de lado" e passaram a prestar apoio à juíza, assinando abaixo-assinados a seu favor e prestigiando sua presença em eventos municipais.

Após a formalização da reclamação, alguns advogados entraram individualmente com incidentes de suspeição em todos os processos que detinham na vara em que a magistrada é titular. O problema da imparcialidade dos juízes é tratado juridicamente como um "incidente de suspeição".Esses "incidentes"são hipóteses abstratas previstas pelas regras jurídicas no Código de Processo Civil em que, a imparcialidade do juiz está afetada a ponto de impossibilitá-lo de atuar na causa, como por exemplo, ser "amigo íntimo" ou "inimigo" de uma das partes envolvidas no processo segundo os livros da área de direito (DIDIER JUNIOR, 2015, p. 677).

$\mathrm{Na}$ comarca, foi redigido um primeiro incidente de suspeição coletivo que contou com 96 assinaturas de advogados, esse documento teve apenas uma representação política, pois juridicamente não era válido, uma vez que a suspeição deve ser alegada individualmente e em 
cada processo. Diante disso, para obter a validação da suspeição juridicamente, era preciso que cada advogado a alegasse em todos os seus processos de competência da vara da juíza. No entanto, neste momento, de apresentação das suspeições individualmente, esse grupo de 96 advogados reduziu para, em torno, de 20 e já contou com 3 desistências.

A arguição desse incidente gera a suspensão do processo.Neste caso, a juíza não aceitou nenhuma suspeição. Assim, a grande maioria dos processos aguarda há mais de um ano serem remetidos ao TJMG para julgamento. Nesse tempo, os processos estão paralisados. Assim que distribuídas as suspeições, os advogados relatavam com frequência que a secretaria da vara informava a seus clientes que "os processos não andavam por culpa dos advogados que pediram as suspeições”. Eram aproximadamente 900 processos. Com apenas quatro remetidos à segunda instância para julgamento dos “incidentes",os advogados se queixavam de estar sem condições de trabalho, uma vez que não recebiam seus honorários, pois, é comum, que os advogados recebam quando concluído o julgamento em primeira instância.

Ogrupo ajuizou as suspeições e se manifestou com mais intensidade. Diante destas tensões, este grupo passou a ser reconhecido, por alguns pares profissionais, e a se autodenominar "grupo dos corajosos". Essa divisão intraprofissional (re)significou o sentido da identidade destes profissionais. A "briga com a juíza" passou a ser, também, a "briga entre os advogados".

Eles pararam de se cumprimentar. Um dia, num encontro num bar organizado pelos “corajosos”, um interlocutor com trânsito entre os dois grupos fez o apelo aos colegas: “- Advogado não briga com advogado, gente! Briga com juiz, promotor... com advogado não!’ Mas eles não se convenceram, uma interlocutora respondeu como crítica aos colegas que não se manifestavam e àqueles que defendiam à juíza que "advogado tinha que ter coragem"seguida pela concordância dos colegas. Na sala ocupada pela OAB no Fórum da comarca, foi afixado no quadro de aviso um cartaz com os dizeres "A advocacia não é profissão de covardes" (Sobral Pinto).

Conforme os interlocutores explicaram, os advogados favoráveis à juíza contavam com certos "privilégios", como era falado entre os "corajosos", como o de possuírem acesso assegurado ao gabinete da juíza.Durante este período, o rompimento foi tão brusco que a festa de fim de ano entre os advogados em 2016 foi realizada de forma separada. Essa festa acontece quase todos os anos e é organizada e custeada pela $\mathrm{OAB}$, variando em razão do caixa disponível. É um momento bastante informal em que os advogados confraternizam entre si e com suas famílias reunindo a grande maioria dos "advogados militantes" da comarca. 
Todavia, a festa de 2016 seria diferente. A Subseção estava com pouco dinheiro e o Presidente, conhecido por ser "pão-duro", como relataram alguns interlocutores, decidiu que não haveria festa naquele ano. O presidente por sua vez, dizia que não haveria festa "pois a Subseção nada tem a comemorar", referindo-se ao conflito coma juíza. Tendo isso em vista, o grupo de advogados que se posicionou publicamente contrário à juíza e se mobilizou redigindo denúncias à ouvidoria do tribunal e entrando, individualmente, com os incidentes de suspeição, decidiu fazer sua própria festa.

Foi possível observar no transcorrer desse evento que eles estavam ressentidos com a falta de solidariedade dos demais colegas, que não apenas optaram por não se manifestar no conflito, mas se posicionaram “do lado da juiza”. Um interlocutor explicou que aqueles ali presentes formavam um "grupo de advogados corajosos que não ficaram com medo nem se acovardaram em seguir com as reclamações contra a magistrada”. Por causa disso, esse grupo decidiu não convidar para a festa o restante dos advogados.

Da mesma forma, não foram convidados para a confraternização que ocorreria no dia seguinte, organizada pelo grupo favorável à juíza. “Os corajosos”falavam dessa confraternização de forma pejorativa, segundo eles, "não apareceria ninguém" e alguns diziam, em forma jocosa, que iriam até o restaurante onde ela aconteceria.

A manifestação daqueles a favor da juíza ocorreu na assinatura de um documento de apoio a ela que elogiava seu trabalho e fazia referência às críticas do grupo "corajoso" como "maledicências". Esse documento foi publicado no Facebook por uma advogada, mas, rapidamente, excluído. Essa exclusão foi vista pelos “advogados corajosos”, segundo alguns interlocutores, como uma forma de preservar um apoio "anônimo” à juíza.

Os advogados favoráveis à juíza se mobilizaram e foram à Belo Horizonte para uma reunião com o Presidente da OAB/MG. De acordo com o relato de alguns advogados, eles fizeram a "defesa da juíza" e disseram que o "problema" da comarca estaria na atuação do outro juiz e não da juíza.

Além disso, a Câmara de Vereadores da cidade concedeu à juíza um título honorífico de "Cidadã" local. Alguns dos advogados aliados estiveram presentes nessa cerimônia e dois deles, inclusive, fizeram discursos em homenagem à juíza na solenidade. $O$ clima da cerimônia foi orientado pela existência do conflito entre os pares profissionais.

O primeiro advogado a discursar ocupava o cargo de procurador do município e disse, em seu discurso, que "-Toda a sociedade (...) [referência ao nome da cidade] estava ao lado da juíza, apenas uma meia dúzia contra”. Foi aplaudido pela plateia, constituída em sua 
maioria por funcionários do Fórum e da prefeitura, ao dizer que "a sociedade de bem está aqui hoje" produzindo um apoio explícito à juíza pela plateia presente. E encerrou dizendo que as denúncias contra a magistrada não passariam de "calúnias, difamação e injúrias".

O outro advogado a discursar foi apresentado pelos interlocutores como "um jovem que reside em Belo Horizonte”, logo não militava profissionalmente na comarca, e sendo neto de um ex-deputado estadual, ele teria também pretensões políticas tanto na cidade, quanto na OAB. Ele disse que vivíamos em um contexto de crises, econômica, política e social. Em sua fala, a crise social seria caracterizada por "vários grupos se aparelharem [das instituições] para fazerem uso do discurso" minoritário como sendo um discurso representativo de uma classe. Nesse momento, ele questionava a legitimidade do apoio institucional da OAB aos “advogados corajosos", apesar disso não ter sido dito explicitamente durante o discurso. Esse mesmo argumento foi utilizado pela juíza em sua defesa no tribunal contra a Reclamação feita pela OAB.

Esse advogado afirmou, também, que os conflitos faziam parte da sociedade, mas que “devemos caminhar lado a lado”, ele estava se referindo à sociedade e ao judiciário, pois ressaltava o "peso das canetas" numa referência explícita ao símbolo de poder dos operadores do direito. $\mathrm{O}$ seu argumento consistiu, então, em como "a advocacia não pode se voltar contra a sociedade”. Se a sociedade está ao lado da juíza, homenageando a sua atuação profissional, os advogados não deveriam questioná-la.

Algum tempo depois houve um episódio envolvendo esse advogado, em que uma gravação, sem o seu conhecimento, registrou uma fala em que ele criticava os advogados da comarca dizendo que "eles não sabiam de nada[de direito]", pois "eram muito ruins". Numa categoria pejorativa, explicou que só haveria “advogadinho de porta de cadeia” na cidade. Não tivemos acesso à essa gravação, pois ela não foi disponibilizada. No entanto, os boatos sobre ela se espalharam entre os "advogados corajosos".

As denúncias formalizadas pela $\mathrm{OAB}$ e pelos advogados na ouvidoria do site do TJMG se converteram em um procedimento de sindicância. Em razão disso, dois representantesda corregedoria do tribunal estiveram na cidade para "tomar depoimentos". $\mathrm{O}$ rito ocorreu no Fórum, no salão do Júri que foi "lacrado", pois se tratava de procedimento sigiloso. Estavam presentes dois juízes auxiliares da corregedoria, a juíza acompanhada de seu advogado, o presidente e o vice-presidente da AMAGIS (Associação dos Magistrados Mineiros) e o procurador de prerrogativas da OAB que, ao solicitar aos desembargadores, teve sua presença concedida. Não foi possível acompanhar o procedimento, pois a juíza 
auxiliar não autorizou nossa presença, justificando a negativa pelo caráter sigiloso da sindicância.

Durante esse dia os advogados contrários à juíza, eram um pouco mais de 20 profissionais no período mais cheio, se manifestaram na porta do Fórum. Foram vestidos de preto e com os adesivos afixados na roupa. Logo pela manhã, às 9h, se posicionaram na porta do Fórum e ficaram no prédio até por volta de 18h50. A manifestação não envolveu discursos, nem desagravos, apenas a presença dos advogados durante todo o dia no prédio. Apesar desses profissionais estarem ali, não trabalharam nesse dia. A presença era, unicamente, uma forma de protesto.

Em contrapartida, no segundo andar, onde ocorriam os depoimentos, também havia alguns advogados. Esses três profissionais não vestiam preto e aguardavam para serem atendidos no gabinete da juíza, segundo os interlocutores, para "lhe prestar solidariedade”.

Apesar dessa divisão entre os advogados da cidade, o grupo dos "corajosos" reconhecia que a "briga com a juiza” produziu maior interação e solidariedade entre eles. Uma interlocutora disse que antes eles não se encontravam muito nem se reuniam como passaram a fazer em decorrência do conflito. As disputas interprofissionais e intraprofissionais produziram uma identidade sobre a forma de identificação pela expertise profissional. Um advogado passou a frequentar rotineiramente o escritório do outro. Quando se encontravam nos arredores ou nos corredores do Fórum sempre paravam para conversar. Marcavam de se encontrar nos bares da cidade.

Além disso, a sociação entre esses profissionais produziu novas relações de sociabilidade profissional, em queadvogados de escritórios diferentes se reuniam para discutir um "caso jurídico" de interesse dos mesmos; profissionais que antes não se conheciam passaram a se auxiliar na confecção de peças processuais. Ou quando algum deles narrava uma ação da juíza considerada como uma afronta ao direito do advogado, todos se envolviam no debate e se indignavam pelo colega.

\section{O conflito como fenômeno sociológico e como categoria nativa}

Do ponto de vista dos “corajosos”, o conflito é percebido não com um viés negativo, mas como algo positivo. Na medida em que abriga interações entre os atores sociais, sendo elas de convergência, ou, mesmo, de divergência. Sobre isso, Simmel (1983) explica que se a 
indiferença representa a negatividade pura, o conflito, por sua vez, estaria relacionado aos fenômenos sociológicos positivos, pois se constitui enquanto uma forma de sociação.

De acordo com esse autor, uma sociedade que seja real é o resultado de interações harmônicas e desarmônicas, de associações e de competições entre os atores, o que lhe atribui uma certa configuração e unidade. $\mathrm{O}$ autor explica que a unidade de que fala é composta por um todo relacional que abarca interações unitárias e duais, trata-se da totalidade das relações de concordância e discordância entre os indivíduos numa interação. Para Simmel (1983) uma sociedade sem conflitos não passa, então, de mera especulação imaginativa, pois é empiricamente irreal.

Assim, o conflito descrito entre a juíza e os advogados provocou e ressignificou uma série de interações entre os próprios advogados e entre eles e a juíza. Sociabilidades e empatia foram mobilizadas, como a união do grupo "corajoso", assim como também relações de competição e identificação se estabeleceram, o que se caracterizou pelo afastamento e pela divisão entre os advogados apoiadores da juíza e aqueles contrários a ela.

Da mesma forma, as relações entre a juíza e os advogados se modificaram, uma vez que a magistrada passou a negociar o apoio de alguns profissionais da advocacia. Seus apoiadores passaram a ter acesso ao gabinete, por exemplo, como foi explicado pelos interlocutores. Embora o conflito tenha sido identificado como algo negativo como explicado por Roberto DaMatta(1998) em sua análise sobre as relações hierárquicas, os “corajosos" experimentaram um intenso processo de sociação que produziu significados positivos numa forma reconhecida de sociabilidade profissional.

Embora existam pontos de vista que consideram o conflito como "normal”. A "briga com a juiza" foi tratada pelos envolvidos e pelas instituições que os representam como um problema a ser resolvido da mesma forma como a cultura jurídica brasileira orienta a administração dos conflitos em âmbito judicial. O conflito foi encarado a partir de uma lógica do contraditório, onde é estabelecido um dissenso infinito, em que as partes envolvidas devem discordar sobre tudo, até que um terceiro "neutro" declare uma decisão que arbitre perdedores e vencedores (KANT DE LIMA, 2009).

Nessa perspectiva, os conflitos são encarados sob um ponto de vista negativo, são percebidos como um "problema" que deve ser eliminado. A própria ausência de composição das tensões entre advogados e juíza até o momento, bem como falas do presidente da $\mathrm{OAB} / \mathrm{MG}$ e do corregedor do TJMG de que a situação na cidade seria "o maior problema" do judiciário no estado de Minas representam esse modo, dos atores, de vivenciar o conflito. 


\title{
A “briga com a juíza” como uma questão de prerrogativas
}

As prerrogativas profissionais estão definidas no site da $\mathrm{OAB} / \mathrm{MG}$ da seguinte forma

\begin{abstract}
As prerrogativas profissionais estão elencadas ao longo de toda a legislação atinente à classe, em especial nos artigos 6 e 7 do Estatuto da $\mathrm{OAB}$, sendo responsáveis por permitir aos advogados a independência e inviolabilidade necessárias para o exercício de seu mister em sua plenitude, não podendo ser entendidas como privilégios e sim garantia da própria sociedade. Seu destinatário final, portanto, não é o advogado mas o cidadão.
\end{abstract}

De acordo com o Estatuto da Ordem as prerrogativas profissionais são direitos assegurados aos advogados no exercício da profissão. Esta lei prescreve as prerrogativas. Para os operadores do direito, há uma diferença entre as prerrogativas e os privilégios (RAMOS, 2003; MAMEDE, 2003; FERNANDES, 2004). As prerrogativas profissionais da advocacia não são privilégios na medida em que argumentam que elas são garantias legais responsáveis por viabilizar o trabalho do advogado e conter os excessos de poder dos agentes do estado.

A defesa das prerrogativas, segundo os operadores do direito, vem sempre justificada pela afirmação da indispensabilidade do advogado na produção da justiça, isto é, na defesa do monopólio excludente sobre os assuntos jurídicos em nossa sociedade. Dessa forma, a argumentação se divide em duas bases, defender as prerrogativas profissionais é fazer uma defesa da advocacia enquanto profissão e é uma defesa do direito dos jurisdicionados a um processo judicial democrático. Por essa última razão, os advogados autores mencionam que mais do que um direito, a defesa das prerrogativas seria um dever do advogado que não deveria se esquivar diante do desrespeito de suas garantias profissionais.

Essa leitura sobre as prerrogativas instrui e dialoga, também, com a forma como meus interlocutores significaram "a briga". Por se tratar de uma questão de prerrogativas, o que está em jogo éa discussão sobre condições de trabalho da advocacia em situação de competição interprofissional. É a própria sociabilidade profissional que está em jogo, pois “conter os excessos de poder estatais” é uma luta pela autonomia da advocacia.

A categoria "coragem" aparece, então, imbricada à identidade profissional da advocacia. Assim, o que é identificado como "coragem" pelos advogados se produz conforme se modificam as condições sociais da profissão e se atualizam as identidades profissionais, o que significa ser um advogado. 
Eliot Freidson (1998) ressalta em "Renascimento do Profissionalismo" que a principal característica que diferencia uma profissão de uma ocupação é o controle que a primeira tem sobre o próprio trabalho, tendo seus trabalhadores a autonomia para decidirem o que fazem e a maneira como fazem, o que de acordo com o autor opõe-se ao exercício da autoridade administrativa sobre o trabalho (FREIDSON, 1998, p.99/100). De acordo com Freidson (1998), a característica principal da autoridade administrativa é justamente o direito legítimo de exercer o controle imperativo de uma ocupação. Nesse sentido, o autor explica: "A administração pode controlar os termos e as condições do trabalho em virtude de um mercado de trabalho comprador, mas o trabalhador profissional controla o próprio trabalho, e o próprio trabalho é a chave da produção". (1998, p. 100).

O que possibilita às profissões essa autonomia é a autoridade da expertise, baseada na crença de que apenas certas especializações da atividade laboral possuem competência para executar satisfatoriamente determinadas tarefas. É essa mesma autoridade que legitima que um trabalhador obtenha o controle sobre o trabalho de outros “(...) quando existe a crença na interdependência funcional desses para ligar seu trabalho ao dele, e quando existe a crença numa maior relevância de seu trabalho bem como na superioridade de seu conhecimento e sua competência em comparação com os outros na divisão do trabalho." (Freidson, 1998, p. 101).

Ao chegar à comarca a juíza, então, passou a instituir novas políticas de trabalho à advocacia, que compreendiam maneiras diversas de se portar em audiências e de se executar o trabalho próprio dos advogados. A partir dessa leitura, a alegação da violação das prerrogativas surge como uma defesa jurídica, mas também política, da profissão, no sentido de se discutir diretamente a questão da autonomia profissional da advocacia e a sua não vinculação hierárquica à magistratura. É nesse sentido que a advogada ao se reportar a seu órgão de classe reiterou que, apesar da juíza se julgar superior a ela, não haveria qualquer hierarquia entre advogada e juíza: "de quem "acha" que é melhor que eu hierarquicamente, mas que infelizmente para ela, não temos nenhuma hierarquia." (Reclamação $\mathrm{OAB})$. A principal questão que orienta a percepção dos interlocutores sobre o conflito é, portanto, a defesa da advocacia enquanto profissão.

Conforme ressalta Maria da Glória Bonelli (1998) é preciso considerar que num ambiente como o mundo do trabalho judicial,em que convivem em interdependência diversas especializações profissionais, há a formação de um campo movido pela interação competitiva entre esses diferentes atores profissionais (BONELLI, 1998). Bonelli (1998) explica que ao se relacionarem umas com as outras, essas profissões formam uma estrutura que gera suas 
próprias interdependências e distintas perspectivas sobre o que é justiça. A autora considera, então, que tais interações no desenvolvimento prático da atividade profissional constituem um sistema profissional, apesar de essas ocupações se organizarem de forma independente com carreiras próprias, isto ocorre, em grande parte, por compartilharem o mesmo objeto de atuação, qual seja, a justiça, ainda que sob sentidos não idênticos.

Diante disso, as prerrogativas profissionais da advocacia representam um importante instrumento político da profissão, na medida em que constituem uma das formas de ampliação da delimitação de sua jurisdição de atuação, o reforço constante à questão de sua autonomia em relação as demais profissões fronteiriças do "mundo do direito", bem como, a reafirmação de um discurso de indispensabilidade do advogado à sociedade como prestador de um serviço essencial de interesse aos cidadãos.

Nesse contexto, a narrativa apresentada não trata apenas da manifestação da competição interprofissional entre advogados e juíza, mas aborda como essa forma de tensão entre profissões que se situam em áreas de atuação vizinhas, diante da ausência de administração do conflito, reverberou para dentro da própria profissão da advocacia. Assim, a competição intraprofissional, no caso estudado, foi (re)significada a partir das disputas interprofissionais, com a contraposição de dois grupos de advogados (a favor e contrário à juíza) que passaram a concorrer entre si para legitimar a identidade profissional mais próxima a cada um deles.

Dessa forma, para os atores com quem dialoguei a categoria "coragem" foi mobilizada como requisito essencial de distinção entre profissionais da advocacia e, portanto, como constituinte da identidade profissional dos advogados locais. Isso possibilita perceber, conforme o argumento de Freidson (1998), como essas identidades profissionais são construídas a partir das relações entre os profissionais, ao invés de se constituírem enquanto categorias isoladas de outras interações.

\section{Considerações Finais}

O objetivo deste trabalho foi discutir como as identidades profissionais dos advogados são construídas a partir das interações contextuais entre esses profissionais, não apenas os pares, mas também, entre profissões diferentes que compartilham de questões de trabalho em comum. Assim, consideramos os processos de sociação profissional no "mundo do direito" 
como abrangidos tanto por interações harmônicas, que resultaram no reconhecimento de uma sociabiliadade profissional entre os atores que se identificaram como iguais, "os corajosos", quanto por interações divergentes, que ocasionaram situações conflituosas.

Dessa forma, partindo-se de uma visão do conflito enquanto um fenômeno sociológico positivo foi possível compreender como a disputa entre os advogados e uma juíza numa cidade do interior de Minas Gerais produziu uma mobilização em defesa da advocacia como profissão, autônoma e produtora de seus próprios controles. A defesa das prerrogativas pelos interlocutores-advogados, como questão central no conflito com a juíza, representa a centralidade de uma ideologia do profissionalismo nessas interações competitivas.

Da mesma maneira, as interações advindas do conflito inicial produziram diferentes formas de reconhecimento profissional, (re)significando as identidades da advocacia naquele contexto local. Categorias como "advogado militante" e, principalmente, "advogado tem que ter coragem", foram mobilizadas pelos atores para estabelecer diferenciações e identificações entre os próprios profissionais.

\section{Referências Bibliográficas}

BEAUD, Stéphanie; WEBER, Florence. Guia de pesquisa de campo: Produzir e analisar dados etnográficos. 2 ed. Petrópolis: Vozes, 2014.

BONELLI, Maria da Gloria. A competição profissional no mundo do Direito. Tempo soc., São Paulo , v. 10, n. 1, p. 185-214, Maio 1998. Disponível em:

$<$ http://www.scielo.br/scielo.php?script=sci_arttext\&pid=S0103-

20701998000100012\&lng=en\&nrm=iso >. Acesso em: 19 set. 2017.

http://dx.doi.org/10.1590/S0103-20701998000100012.

BONELLI, MG. Condicionantes da competição profissional no campo da justiça: a morfologia da magistratura. SADEK, MT., org. In Uma introdução ao estudo da justiça[online]. Rio de Janeiro: Centro Edelstein de Pesquisas Sociais, 2010. pp. 95-116. BONELLI, MG. Condicionantes da competição profissional no campo da justiça: a morfologia da magistratura. SADEK, MT., org. In Uma introdução ao estudo da justiça [online]. Rio de Janeiro: Centro Edelstein de Pesquisas Sociais, 2010. pp. 95-116.

BONELLI, Maria da Glória. Ideologias do profissionalismo em disputa na magistratura paulista. Sociologias, Porto Alegre, ano 7, n. 13, p. 110-135, Jan/Jun. 2005.

BRASIL. Lei n. 8906, de 4 de julho de 1994. Estatuto da Advocacia e a Ordem dos Advogados do Brasil (OAB). Brasília, DF, julho, 1994. 
DAMATTA, R. Carnavais, Malandros e Heróis. Rio de Janeiro: Rocco, 1998.

DIDIER JÚNIOR, Fredie. Curso de Direito Processual Civil. Salvador: Jus Podivm, 2015. 786 p.

FERNANDES, Paulo Sérgio L. Na defesa das prerrogativas do advogado. Brasília: OAB Editora, 2004. $640 \mathrm{p}$.

FREIDSON, Eliot. Renascimento do Profissionalismo. São Paulo: Edusp, 1998.

LIMA, Roberto Kant de. Polícia, Justiça e Sociedade no Brasil: uma abordagem comparativa dos modelos de administração de conflitos no espaço público. Revista de Sociologia e Política, Curitiba, n. 13, p.23-38, nov. 1999.

LIMA, Roberto Kant de. Sensibilidades jurídicas, saber e poder:: bases culturais de alguns aspectos do direito brasileiro em uma perspectiva comparada. Anuário Antropológico, Brasília, p.25-51, 2009.

Semestral. Disponível em: <http://www.dan.unb.br/anuario-antropologico-listagem-dos-numeros/112anuario-antropologico-sumario-20092>. Acesso em: 09 jul. 2015.

MAMEDE, Gladston. A advocacia e a Ordem dos Advogados do Brasil. 2 ed. São Paulo: Atlas, 2003.

Ordem dos Advogados do Brasil - Seção Minas Gerais. Disponível em:

<http://www.oabmg.org.br/>. Acesso em: 08 de ago. de 2017.

MOREIRA-LEITE, Angela. Em tempo de conciliação. Niterói: EDUFF, 2003.

RAMOS, Gisela G. Estatuto da Advocacia: Comentários e Jurisprudência Selecionada. 4 ed. Florianópolis: OAB/SC, 2003. 936 p.

Reportagem sobre o CEJUS: Disponível em: <http://www9.tjmg.jus.br/portal/acoes-e-programas/cineclube/noticias/detalhe-1898.htm\#.WdfPR1tSzIU>. Acesso em: 06 de out. de 2017.

Reportagens sobre o CEJUS: <http://www.iof.mg.gov.br/index.php?/justica/justica/TJ-instala-Cejusem-Monte-Carmelo.html>; <http://anamages.org.br/noticias/tjg-instala-centro-judiciario-de-solucaode-conflitos-em-monte-carmelo>; <http://www.montefm.com.br/noticias/fucamp-firma-conveniocom-tribunal-e-justica-do-estado-de-minas-gerais-tjmg/>. Acesso em 06 de out. de 2017.

Reportagem sobre o CEJUS no TJMG: Disponível em:

<http://www9.tjmg.jus.br/corregedoria/fiscalizacao-do-foro-judicial/correicao-

extraordinaria/correicao-extraordinaria.htm>. Acesso em: 07 de out. de 2017.

SIMMEL, Georg, O conflito como sociação. (Tradução de Mauro Guilherme Pinheiro Koury). RBSE - Revista Brasileira de Sociologia da Emoção, v. 10, n. 30, pp. 568-573. ISSN 1676- 8965.

http://www.cchla.ufpb.br/rbse/Index.html.

Site OAB Federal: Disponível em: <http://www.oab.org.br/>. Acesso em: 08 de ago. 2017. 
TORRES DE MELO RANGEL, Victor. A ambivalência de ser conciliador: Como eles se veem e são vistos. Confluências, vol 15, n. 2, 2013, p. 61-74. 